\title{
STUDIES ON AMINO ACID EXCRETION IN MAN. III. AMINO ACID LEVELS IN PLASMA AND URINE OF NORMAL MEN FED DIETS OF VARYING PROTEIN CONTENT ${ }^{1}$
}

\author{
BY JOSEPH B. KIRSNER, A. LEONARD SHEFFNER, AND \\ WALTER LINCOLN PALMER \\ (From the Frank Billings Medical Clinic, Department of Medicine, University of Chicago)
}

(Received for publication October 13, 1949)

Current emphasis on the use of proteins in the treatment of various disorders of the alimentary tract has stimulated a comparative study of certain aspects of protein metabolism in normal persons and in patients with gastro-intestinal disease. In addition to the usual nitrogen balances, microbiological assays were made of eight amino acids in food, acid-hydrolyzed whole plasma, tungstic acid filtrates of plasma (free amino acids), acid-hydrolyzed tungstic acid filtrates of plasma (free plus combined amino acids), hydrolyzed urine, and in feces. The amino acids measured were methionine, lysine, arginine, histidine, leucine, isoleucine, valine and threonine. The present paper deals with individual amino acid levels in the food, plasma, and urine of two normal adult men fed isocaloric diets of differing protein content. The data indicate that the fasting levels of amino acids in plasma are relatively constant, and that the excretion of amino acids in the urine does not fluctuate significantly despite considerable variation in amino acid intake.

\section{METHOD OF STUDY}

\section{A. Subjects}

Two healthy young men were studied in the metabolism section of Billings Hospital. In addition to the standard laboratory procedures, normal results were obtained for the following: (a) urea clearance test of renal function (1); (b) oral glucose tolerance; (c) hepatic function (2-9); (d) carbon dioxide ([10] p. 283), $\mathrm{pH}$ ([10] p. 796) and chloride ([10] p. 835), calcium (11), and phosphorus (12) content of serum; (e) plasma proteins (13) ; and ( $f$ ) gastric secretion (14) (0.1 mg. histamine diphosphate per $10 \mathrm{~kg}$. body weight).

Subject 1, J. D.; initial weight was $70 \mathrm{~kg}$., height $175 \mathrm{~cm}$. The basal metabolic rate, measured by the Benedict-Roth apparatus and calculated according to the standards of Boothby and Berkson, was +4 ; the basal calories were estimated as 1880 .

1 This study was supported in part by grants from the Evaporated Milk Association and American Dairy Association.
Subject 2, R. G. H.; initial weight was $84 \mathrm{~kg}$., height $187 \mathrm{~cm}$. The basal metabolic rate was 0 ; basal calories were estimated as 1990 . The blood and plasma volumes were measured by the Gibson-Evans method (15) at frequent intervals in this subject; the values were relatively constant, averaging 6198 and 2720 cc., respectively.

\section{B. Diet}

Normal activity was permitted. Fluids were allowed ad libitum, but the fluid intake and urine output were measured daily. The only medication consisted of a liquid vitamin B preparation given daily. Though the quantity of protein was varied, the caloric intake was kept uniform by adjustment of the carbohydrate and fat content of the diet. The number of calories was determined on the basis of the basal metabolic rate of each subject, with additional allowances for his usual activity. In Subject 1 , the intake of calories was 3200 , the carbohydrate ranging in the various periods from 403 to 477 gms. and the fat from 110 to 154 gms. In Subject 2, the intake of calories was 3190 , the carbohydrate ranging from 415 to $475 \mathrm{gms}$. and the fat from 103 to $131 \mathrm{gms}$. Two to $4.0 \mathrm{gms}$. of table salt were added to the food each day. Crystalline methionine was added in periods 9 and 10 ; in all other periods the quantity of individual amino acids was varied by changes either in the amount or type of protein. Following a transitional interval of three days, each regimen was studied for two consecutive six-day periods.

\section{Preparation and Analysis of Food, Plasma and Urine}

The food was prepared in the kitchen of the metabolism section by dietitians trained in the problems of metabolic research. The food was weighed on a torsion balance before cooking; salt was the only seasoning; meats were broiled. The quality and quantity of the food were kept uniform throughout each regimen.

For analysis, a 30 to 40 per cent aliquot of a one-day supply of food (excepting pure carbohydrate and fat) was homogenized with distilled water in a Waring blendor. A second aliquot of the same diet was prepared and analyzed approximately one week later; the results of both measurements were averaged.

At the end of each six-day period, following a 10-hour overnight fast, $100 \mathrm{ml}$. of venous blood were drawn, transferred to a screw-capped bottle containing 15 to 30 mg. of heparin, and mixed thoroughly. The blood was centrifuged and the plasma removed immediately. One- 
ml. samples were taken for the measurement of total nitrogen and for the assay of amino acids in acidhydrolyzed whole plasma. Forty-ml. samples were used for the preparation of tungstic acid filtrates, as described by Hier and Bergeim (16). Aliquots of the tungstic acid filtrates were hydrolyzed with hydrochloric acid and assayed for total non-precipitable amino acids.

The urine was voided directly into glass containers and stored under toluene at ice box temperature $\left(3-5^{\circ} \mathrm{C}\right.$.). The total six-day collection was combined and aliquots were taken for various analyses. Urea was measured by the urease method (17), free ammonia by the procedure described in Peters and Van Slyke (10) and the $\mathrm{pH}$ of the urine by the glass electrode method.

The total nitrogen of the food, plasma and urine was determined by a semi-micro-Kjeldahl technique, utilizing the Pregl-Parnas-Wagner apparatus and the digestion mixture of Campbell and Hanna (13). Amino acid assays were carried out by the microbiological method, as described elsewhere $(18,19)$. Recovery of measured amounts of pure amino acids added to the urine before acid hydrolysis ranged from 90 to 110 per cent. The validity of the microbiological procedures used in these studies has been confirmed by Toennies and Gallant (20). Leucine, isoleucine, arginine, histidine, valine and threonine were measured with Streptococcus fecalis; methionine and lysine with Leuconostoc mesenteroides P-60 as the assay organism.

\section{RESULTS}

The body weights of both subjects did not change significantly throughout the study. The total plasma proteins and the albumin-globulin ratios remained normal. The data for amino acids are presented in Tables IA and B. A change in concentration was considered significant if it exceeded the standard deviation ${ }^{2}$ by two or more times.

\section{Individual Amino Acids in Whole Plasma}

The fluctuations in the methionine content of whole plasma in both subjects paralleled the varying intakes of this amino acid in food. For the seven other amino acids, there was no direct correlation between the quantities ingested and the plasma levels. The addition of crystalline DLmethionine to a diet adequate in this amino acid

2 Standard deviation derived from expression:

$$
\text { S.D. } .^{2}=\frac{[\text { M.D. }]^{3}}{n-1}
$$

S.D. $=$ standard deviation; M.D. $=$ mean deviation; $n=$ number of values measured.

TABLE I-A

Intake in food, excretion in urine and fasting normal plasma levels of individual amino acids in two normal men

\begin{tabular}{|c|c|c|c|c|c|c|c|c|c|c|}
\hline \multirow{3}{*}{ 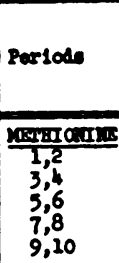 } & \multicolumn{5}{|c|}{ Subjoct I (J.D.) } & \multicolumn{5}{|c|}{ Subjoot 2 (E.G.B.) } \\
\hline & $\begin{array}{l}\text { Intakos } \\
\text { in Tood } \\
(\mathrm{E} .1 \\
\end{array}$ & $\begin{array}{l}\text { Excrotion } \\
\text { Urino } \\
\text { darg) }\end{array}$ & 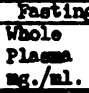 & 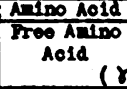 & 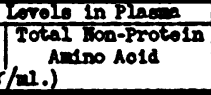 & 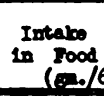 & $\begin{array}{l}\text { Drordion } \\
\text { Oripo } \\
\text { dere) }\end{array}$ & 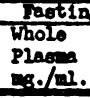 & $\begin{array}{l}\text { ARlpo Ac1d } \\
\text { Proo Afiso } \\
\text { Ac1d }\end{array}$ & 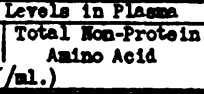 \\
\hline & $\begin{array}{r}10.20 \\
6.00 \\
9.24 \\
7.14 \\
23.14\end{array}$ & $\begin{array}{l}0.03 \\
0.05 \\
0.04 \\
0.04 \\
0.07\end{array}$ & $\begin{array}{l}0.59 \\
0.39 \\
0.76 \\
0.46 \\
0.98\end{array}$ & $\begin{array}{l}3.9 \\
5.0 \\
5.0 \\
3.3 \\
6.9\end{array}$ & $\begin{array}{l}3.4 \\
5.5 \\
5.2 \\
3.2 \\
6.7\end{array}$ & $\begin{array}{r}12.78 \\
6.78 \\
12.66 \\
10.50 \\
16.50\end{array}$ & $\begin{array}{l}0.06 \\
0.06 \\
0.08 \\
0.07 \\
0.12\end{array}$ & $\begin{array}{l}0.89 \\
0.54 \\
0.58 \\
0.49 \\
0.77\end{array}$ & $\begin{array}{l}6.3 \\
6.2 \\
5.7 \\
4.5 \\
6.1\end{array}$ & $\begin{array}{l}3.4 \\
5.9 \\
5.0 \\
4.9 \\
7.7\end{array}$ \\
\hline $\begin{array}{l}\frac{2 r s 515}{1,2} \\
3,4 \\
3,6 \\
7,8 \\
9,10\end{array}$ & $\begin{array}{r}27.84 \\
9.90 \\
28.98 \\
18.72 \\
18.72\end{array}$ & $\begin{array}{l}0.29 \\
0.32 \\
0.36 \\
0.31 \\
0.37\end{array}$ & $\begin{array}{l}7.9 \\
6.2 \\
7.7 \\
6.4 \\
6.98\end{array}$ & $\begin{array}{l}23.5 \\
24.2 \\
27.0 \\
20.8 \\
28.0\end{array}$ & $\begin{array}{l}45.0 \\
45.0 \\
47.0 \\
36.1 \\
60.5\end{array}$ & $\begin{array}{l}35.58 \\
16.56 \\
32.60 \\
28.80 \\
28.80\end{array}$ & $\begin{array}{l}0.85 \\
0.73 \\
0.95 \\
0.88 \\
0.80\end{array}$ & $\begin{array}{l}8.4 \\
8.66 \\
8.17 \\
8.40 \\
8.17\end{array}$ & $\begin{array}{l}28.2 \\
21.7 \\
27.9 \\
24.7 \\
31.2\end{array}$ & $\begin{array}{l}65.0 \\
56.5 \\
69.3 \\
60.2 \\
69.0\end{array}$ \\
\hline $\begin{array}{c}\frac{A B C h I n g}{1,2} \\
3,4 \\
5,6 \\
7,8 \\
9,10\end{array}$ & $\begin{array}{l}22.20 \\
11.64 \\
20.52 \\
19.08 \\
19.08\end{array}$ & $\begin{array}{l}0.12 \\
0.09 \\
0.14 \\
0.12 \\
0.16\end{array}$ & $\begin{array}{l}3.72 \\
2.99 \\
3.65 \\
3.29 \\
3.72\end{array}$ & $\begin{array}{l}14.9 \\
12.0 \\
15.2 \\
17.2 \\
18.8\end{array}$ & $\begin{array}{l}43.0 \\
41.0 \\
28.3 \\
22.2 \\
30.9\end{array}$ & $\begin{array}{l}29.82 \\
14.94 \\
28.80 \\
28.02 \\
28.02\end{array}$ & $\begin{array}{l}0.22 \\
0.19 \\
0.18 \\
0.19 \\
0.17\end{array}$ & $\begin{array}{l}4.32 \\
4.64 \\
4.41 \\
3.77 \\
3.49\end{array}$ & $\begin{array}{l}18.6 \\
15.9 \\
25.7 \\
26.5 \\
15.9\end{array}$ & $\begin{array}{l}49.8 \\
38.9 \\
43.8 \\
37.2 \\
46.9\end{array}$ \\
\hline $\begin{array}{c}\text { Hrgrmin } \\
1,2 \\
3,4 \\
5,6 \\
7,8 \\
9,10\end{array}$ & $\begin{array}{r}11.52 \\
6.18 \\
11.52 \\
10.80 \\
10.80\end{array}$ & $\begin{array}{l}0.77 \\
0.44 \\
0.80 \\
0.72 \\
0.90\end{array}$ & $\begin{array}{l}2.23 \\
2.20 \\
2.34 \\
2.14 \\
2.40\end{array}$ & $\begin{array}{l}15.9 \\
17.7 \\
12.5 \\
17.0 \\
17.3\end{array}$ & $\begin{array}{l}24.7 \\
21.6 \\
21.6 \\
20.8 \\
20.5\end{array}$ & $\begin{array}{r}16.14 \\
7.68 \\
23.90 \\
13.08 \\
13.08\end{array}$ & $\begin{array}{l}2.76 \\
1.84 \\
2.36 \\
2.44 \\
2.48\end{array}$ & $\begin{array}{l}2.12 \\
2.20 \\
2.26 \\
2.20 \\
.2 .29\end{array}$ & $\begin{array}{l}23.2 \\
23.5 \\
14.4 \\
14.2 \\
.17 .0\end{array}$ & $\begin{array}{l}24.5 \\
22.7 \\
27.5 \\
23.7 \\
28.8\end{array}$ \\
\hline
\end{tabular}

(a) 6.0 gms. crystalline DL-methionine added in periods 9 and 10, supplementing diet of periods 7 and 8 .

(b) All values are averages of data for two successive six-day periods.

(c) The apparently lower values for total non-precipitable methionine as compared with free amino acid values are due to the experimental error inherent in the microbiological method.

(d) The term "Total non-protein amino acids" should read "Total non-precipitable amino acids." 
TABLE I-B

Intake in food, excretion in urine and fasting normal plasma levels of individual amino acids in two normal men

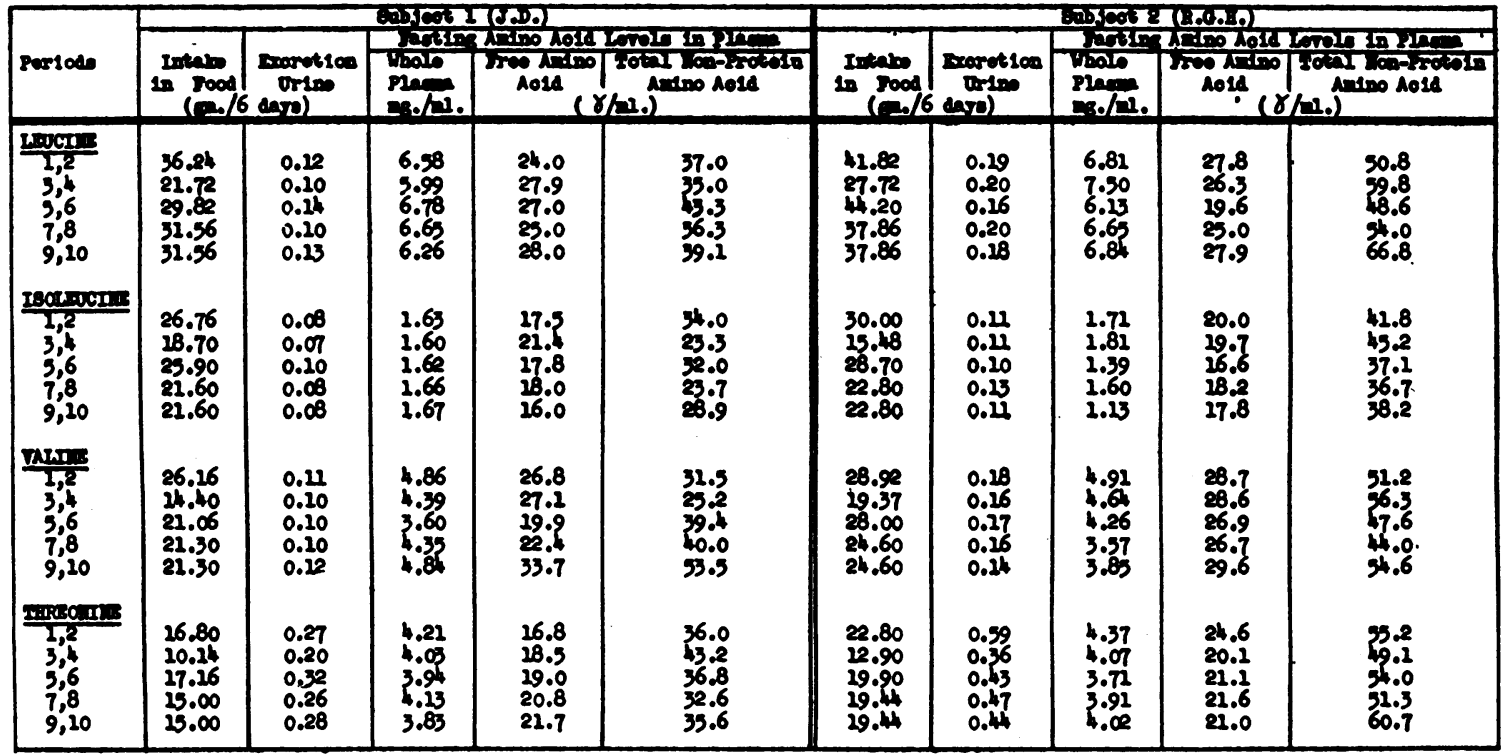

(See footnotes under Table I-A.)

was accompanied only by a slight rise in the total methionine content of plasma in both subjects.

\section{Individual Free Amino Acids in Plasma}

The free amino acid content of plasma fluctuated slightly but did not parallel the varying intakes. Free methionine and free lysine increased minimally in both individuals after the addition of crystalline methionine to the diet; the concentrations of the other six amino acids did not vary significantly.

\section{Combined Non-Precipitable Amino Acids in Plasma}

Seven of the eight amino acids were consistently present, to some extent, in a non-precipitable "bound" form, i.e., not precipitated with tungstic acid, yet not available to the assay organisms for growth. Non-precipitable combined methionine was found only in minute quantities or was totally absent. The combined non-precipitable amino acids in plasma varied in a random manner in both subjects. The addition of crystalline methionine was accompanied by slight increases in the levels of methionine and lysine only.

\section{Amino Acid Output in Urine}

The output of amino acids in the urine, as determined microbiologically, was very small (Tables
IA and B). The pattern of relative rates of excretion for the various amino acids was not directly related to the amounts taken in the food. Thus, the outputs of leucine and arginine were similar, although the intake of arginine was much smaller. The excretion of threonine exceeded that of valine although its intake was less. Histidine was excreted proportionately in far greater quantities than the other amino acids, averaging for the two subjects approximately 13 per cent of the intake. There appeared to be no correlation between the quantities of amino acids in the urine and the volume of urine or the output of urea nitrogen.

The fluctuations in excretion of histidine and threonine apparently paralleled the varying intakes. However, the outputs of methionine (periods 1-8), lysine, arginine, leucine, isoleucine and valine remained relatively constant. The quantity of methionine in the urine increased when $1.0 \mathrm{gm}$. of crystalline DL-methionine was added daily to a diet containing adequate amounts of this amino acid; however, the increment approximated only 0.5 per cent of the added methionine in J. D. and 0.7 per cent in R. G. H. The excretion of the other amino acids did not change significantly during the periods of methionine supplementation.

Subject 1 remained in approximate nitrogen 
balance, and Subject 2, in positive nitrogen balance throughout the study (Table II). Retention of nitrogen increased markedly during periods 5 and 6 , when the intake of protein was increased. The excretion of urea nitrogen, as expected, paralleled the quantity of nitrogen ingested. The small changes in output of free ammonia nitrogen did not appear significant.

\section{Effect of Low Intake of Amino Acids}

The effect of a markedly reduced intake of amino acids was investigated in Subject 2 during two additional periods, not included in the tables. In (a) the source of protein was a solution of peptone treated with 3 per cent hydrogen peroxide; the quantity of methionine ingested during the sixday period was decreased to 2.3 gms. In $(b)$ the peptone solution was treated with 30 per cent hydrogen peroxide, the total intake of methionine being further reduced to $0.90 \mathrm{gm}$. In both periods, 1.25 gms. each of DL-tryptophane, L-tryosine, and L-cystine were added daily to compensate for the destruction of these amino acids by the peroxide. No effort was made to maintain the other amino acids at their original levels. The reduction in the intake of methionine in period $(b)$ to 7.4 per cent of the subject's previous average intake was not accompanied by a significant reduction in the methionine content of hydrolyzed whole plasma; however, the levels of free methionine decreased markedly. Although the intakes of the remaining amino acids, with the exception of arginine, also were considerably lower than in any of the previous periods, the concentrations of these seven amino acids in whole plasma likewise did not change. However, free lysine, histidine, leucine, isoleucine, valine and threonine decreased significantly; the concentration of free arginine did not vary. The combined non-precipitable levels in plasma did not diminish during the administration of the peptone diet. Supplementation of this regimen with $1.0 \mathrm{gm}$. of DL-methionine daily was not accompanied by significant changes in the concentrations of the eight amino acids in hydrolyzed whole plasma, or in the free amino acid levels. Non-precipitable combined methionine, lysine, arginine, and threonine increased slightly. The sixday output of methionine in the urine decreased from $0.108 \mathrm{gm}$. in period (a) to $0.04 \mathrm{gm}$. in period (b) ; the latter value, however, was smaller by only 27 per cent than the values obtained during the ingestion of much larger amounts of methionine. Of particular interest, perhaps, was the increased excretion of lysine, leucine, isoleucine,

TABLE II

Nitrogen balances and excretion of urea and free ammonia nitrogen in subjects J.D. and R.G.H.

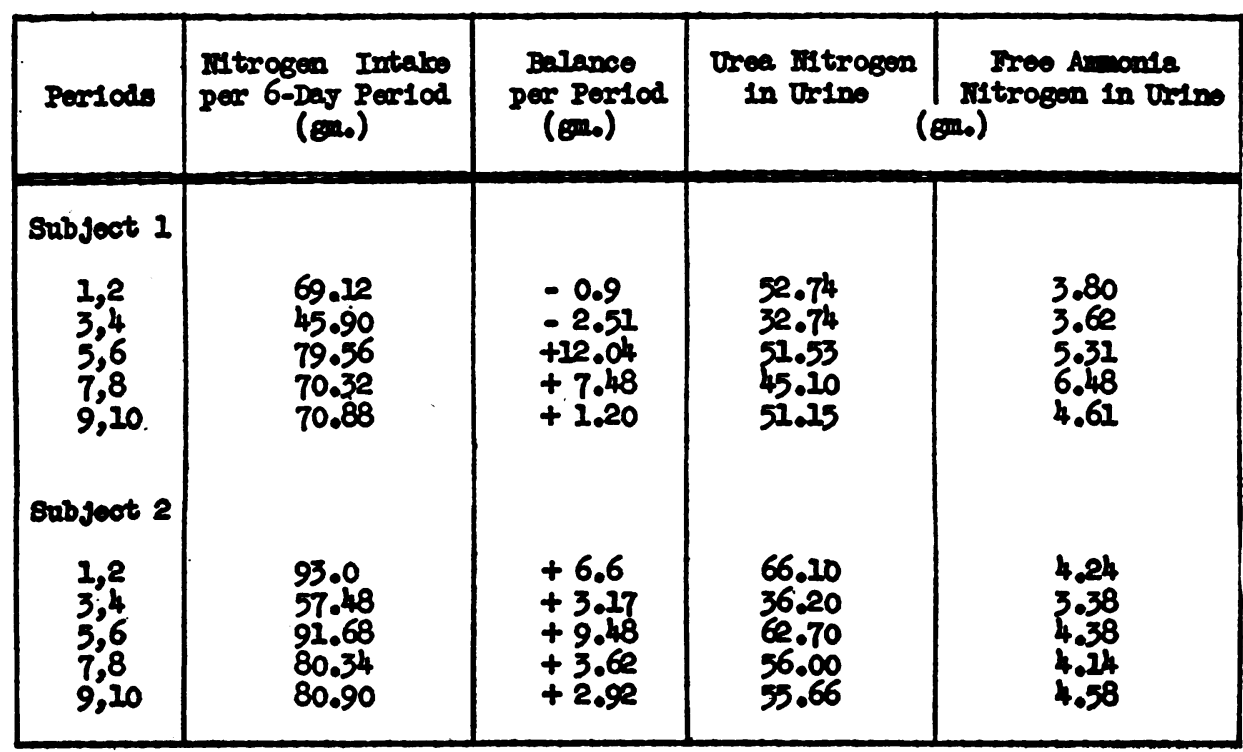

$0.56 \mathrm{gm} . \mathrm{N}$ in periods 9 and 10 in form of added crystalline methionine.

All values are averages of data for two successive six-day periods. 
valine and threonine, the intakes of which had been reduced markedly. The output of arginine also rose although the quantity ingested was unchanged. The excretion of histidine diminished by 24 per cent, whereas the intake had been lowered by 84 per cent. During the same period $(b)$ the output of urea nitrogen increased and the nitrogen balance became distinctly negative.

\section{COMMENT}

\section{Plasma}

The microbiological values in whole plasma for the eight amino acids are, with the exception of leucine, within the range listed for serum proteins by Block and Bolling (21). The data for leucine reported by the latter investigators were obtained by the oxidative method of Fromegat which, according to Hier et al. (22), yields values higher than are obtained by microbiological assay. The fasting whole plasma level of methionine averaged approximately $0.64 \mathrm{mg}$. per cent as compared with $0.73 \mathrm{mg}$. per cent, noted by Kinsell and his associates (23). The present data for free amino acids in plasma agree with the findings of Hier and Bergeim (24) in a group of 33 normal persons, and with the results for valine and histidine reported by Ackermann et al. (25). The individual amino acid values for the two subjects of this study were similar.

The whole plasma levels of lysine, arginine, histidine, leucine, isoleucine, valine and threonine did not fluctuate significantly although varying amounts were ingested. However, the methionine content of whole plasma apparently paralleled the varying intakes of this amino acid. Non-precipitable methionine accounted for only a minute fraction of these changes. Assuming that the constituent amino acid composition of plasma proteins remains constant, it may be postulated that a portion of methionine in plasma is attached to the surface of plasma proteins, is precipitable with the proteins by tungstic acid, yet does not constitute an integral component of the protein molecule. The concept of serum protein complexes has been discussed by various investigators (26-29). However, more data obviously are necessary to determine the significance of the fluctuations observed with methionine and to establish the validity of this hypothesis.

The effect of increased ingestion of one amino acid upon the individual levels of other amino acids in the blood has been studied only occasionally. Hier (30) found that higher concentrations of free leucine, isoleucine and methionine in the blood of dogs, produced by feeding large amounts of the respective amino acids, were accompanied by decreases in the levels of certain other amino acids. However, the elevation in methionine was associated with a rise in the concentration of lysine. In the present study also, the increase in methionine, produced by the addition of crystalline DLmethionine to the diet, was accompanied by slight rises in the levels of free and combined non-precipitable lysine. The averaged data do not indicate the magnitude of the increase which resulted during the second period of methionine supplementation; the significance of these changes, however, remains to be determined.

\section{Urine}

The microbiological values obtained for total methionine, lysine, arginine, histidine, leucine, isoleucine, valine and threonine in the urine are within the ranges reported by Dunn and his associates (31), Woodson et al. (32), and by Eckhardt and Davidson (33).

Amino acid excretion was extremely small and relatively constant in relation to the amounts ingested. Eckhardt and Davidson similarly found no significant change in the quantity of amino acids excreted by a normal subject given varying amounts of protein. Although the output of methionine increased when the diet was supplemented daily by $1.0 \mathrm{gm}$. of the crystalline DL form, the increment for both subjects averaged only 0.6 per cent of the added methionine. Harper, Kinsell and Barton (34) noted a low output of methionine following its intravenous administration. Similar observations have been made by other investigators with respect to amino acid nitrogen (35).

It is to be noted that the number of calories was maintained at a constant level by adjustment of the carbohydrate and fat content of the diet. The data of Woodson et al. (32) have been interpreted as indicating that the caloric intake does not influence significantly the excretion of amino acids. However, this point has not been established conclusively, in our opinion. Until additional evidence is obtained, it would appear desirable, in studies of amino acid excretion, to control the caloric content of the diet. Preliminary experiments in our 
laboratory suggest that the caloric intake may play a role in the urinary excretion of amino acids.

A small percentage of the amino acids in urine, as measured in this study, may have been derived from protein-like materials; Hanke (36) has reported the presence of a crystalline albumose in normal human urine which was excreted at a rate of approximately $50 \mathrm{mg}$. per day. Analysis of the amino acid composition of a sample of this material indicates, however, that less than 20 per cent of the total amino acids in urine may have been present in this form.

The increased excretion of amino acids in the urine of Subject 2 during the administration of an oxidized solution of peptone is of considerable interest. The oxidation obviously not only reduced the amino acid content, but also apparently disturbed the proper proportions of amino acids; the possible development of a toxic factor cannot be excluded. In this connection, Sauerblich, Pearce and Baumann (37) noted a higher excretion of "free" amino acids in the urine of mice fed diets containing protein of low biological value than among mice given proteins of ordinary or high biological value.

Both subjects remained in approximate nitrogen balance even when fed a moderately low protein diet. Nevertheless, nitrogen retention rose markedly when the intake of protein was increased. This finding suggests, perhaps, that measurements of nitrogen balance alone, at least for short periods of time, may not reveal minimally inadequate intakes of protein.

\section{SUMMARY AND CONCLUSIONS}

1. The amino acids methionine, lysine, arginine, histidine, leucine, isoleucine, valine and threonine were measured microbiologically in the food, plasma and urine of two normal adult men fed a variety of diets. In plasma, analyses were performed on acid-hydrolyzed whole plasma, tungstic acid filtrates (free amino acids), and on acidhydrolyzed tungstic acid filtrates (free plus combined non-precipitable amino acids).

2. The fasting amino acid content of plasma, in general, did not fluctuate significantly despite considerable variation in the quantity of amino acids ingested in the food. Parallel fluctuations in the plasma levels and the amino acid intakes were observed in both subjects only for total methionine.
3. The output of amino acids in the urine was small, averaging 2.5 per cent of the intake. The pattern of relative rates of excretion for the various amino acids was not directly correlated with the respective individual amounts taken in the food.

4. Excretion of six of the eight amino acids was relatively constant despite considerable variations in intake. The outputs of histidine and threonine fluctuated slightly in relation to the varying intakes.

5. The addition of crystalline DL-methionine to a diet adequate in this amino acid was accompanied by increases in the whole plasma levels of methionine and of free and combined non-precipitable methionine and lysine. The urinary output of methionine increased slightly; no significant changes occurred in the excretion of the other amino acids.

6. In one subject the oral administration of a peptone solution treated with hydrogen peroxide and containing markedly reduced quantities of methionine, lysine, histidine, leucine, isoleucine, valine and threonine, was accompanied by definite decreases in the free levels of these amino acids. During the same periods, the amino acid outputs in the urine increased considerably.

\section{ACKNOWLEDGMENTS}

The authors express their appreciation to Dr. Martin E. Hanke for providing the sample of albumose; to Miss Blanche Parish, R.N., for supervision of the collections and care of the subjects; to Miss Minnie Brandt for preparation and administration of the diets, and to the subjects, Mr. John Doull and Mr. Richard Herz, for their cooperation.

\section{BIBLIOGRAPHY}

1. Møller, E., McIntosh, J. F., and Van Slyke, D. D., Studies of urea excretion. II. Relationship between urine volume and the rate of urea excretion by normal adults. J. Clin. Invest., 1928, 6, 427.

2. Ducci, H., and Watson, C. J., The quantitative determination of the serum bilirubin with special reference to the prompt reacting and the chloroformsoluble types. J. Lab. \& Clin. Med., 1945, 30, 293.

3. Sperry, W. M., The determination of cholesterol. J. Biol. Chem., 1937, 118, 377.

4. Bodansky, A., Phosphatase studies. II. Determination of serum phosphatase; factors influencing the accuracy of the determination. J. Biol. Chem., 1933, 101, 93. (Modified Fiske-SubbaRow method for inorganic phosphate. See Reference 12.)

5. Hanger, F. M., Serological differentiation of obstructive from hepatogenous jaundice by flocculation of cephalin-cholesterol emulsions. J. Clin. Invest., 1939, 18, 261. 
6. Maclagan, N. F., Thymol turbidity test: A new indicator of dysfunction (preliminary report). Nature, 1944, 154, 670. (As modified by Mateer, Gastroenterology, 1947, 8, 52.)

7. Rosenthal, S. M., and White, E. C., Clinical application of the bromsulfalein test for hepatic function. J. A. M. A., 1925, 84, 1112.

8. (a) Lipschutz, E. W., A modification of the hippuric acid liver function test. Am. J. Digest. Dis., 1939, 6, 197.

(b) Quick, A. J., Intravenous modification of the hippuric acid test for liver function. Am. J. Digest. Dis., 1939, 6, 716.

9. Schwartz, S., Sborov, V., and Watson, C. J., Urobilinogen. IV. The determination of urobilinogen by means of the Evelyn photoelectric colorimeter. Am. J. Clin. Path., 1944, 14, 598.

10. Peters, J. P., and Van Slyke, D. D., Quantitative Clinical Chemistry, Vol. 2, Methods. Williams and Wilkins Co., Baltimore, 1932.

11. de Souza, H. R., A rapid method for the determination of blood calcium. Hospital (Rio de Janeiro), 1945, 27, 425. Chem. Abstracts, 1946, 40, 916.

12. Fiske, C. H., and SubbaRow, Y., The colorimetric determination of phosphorus. J. Biol. Chem., 1925, 66, 375. Applied to Evelyn Photoelectric Colorimeter, cf. Bulletin No. 460, Rubicon Co., Philadelphia, $\mathrm{Pa}$.

13. Campbell, W. R., and Hanna, M. I., The albumin, globulins and fibrinogen of serum and plasma. J. Biol. Chem., 1937, 119, 15.

14. Bloomfield, A. L., and Polland, W. S., Diagnostic value of studies of gastric secretion. J. A. M. A., 1929, 92, 1508.

15. Gibson, J. G., Jr., and Evans, W. A., Jr., Clinical studies of the blood volume. I. Clinical application of the method employing the azo dye "Evans Blue" and the spectrophotometer. J. Clin. Invest., 1937, 16, 301.

16. Hier, S. W., and Bergeim, O., Microbiological determination of free leucine, isoleucine, valine, and threonine in dog plasma. J. Biol. Chem., 1945, $161,717$.

17. Van Slyke, D. D., and Cullen, G. E., The determination of urea by the urease method. J. Biol. Chem., 1916, 24, 117.

18. Sheffner, A. L., Kirsner, J. B., and Palmer, W. L., Studies on amino acid excretion in man. I. Amino acids in urine. J. Biol. Chem., 1948, 175, 107.

19. Sheffner, A. L., Kirsner, J. B., and Palmer, W. L., Studies on amino acid excretion in man. II. Amino acids in feces. J. Biol. Chem., 1948, 176, 89.

20. Toennies, G., and Gallant, D. L., Bacteriometric studies. I. Factors affecting the precision of bacterial growth responses and their measurement. J. Biol. Chem., 1948, 174, 451.

21. Block, R. J., and Bolling, D., The Amino Acid Composition of Protein and Foods. Charles C. Thomas, Springfield, 1945.
22. Hier, S. W., Graham, C. E., Friedes, R., and Klein, D., The microbiological determination of amino acids in animal proteins. J. Biol. Chem., 1945, 161, 705.

23. Kinsell, L. W., Harper, H. A., Barton, H. C., Hutchin, M. E., and Hess, J. R., Studies in methionine and sulfur metabolism. I. The fate of intravenously administered methionine in normal individuals and in patients with liver damage. $J$. Clin. Invest., 1948, 27, 677.

24. Hier, S. W., and Bergeim, O., The microbiological determination of certain free amino acids in human and dog plasma. J. Biol. Chem., 1946, 163, 129.

25. Ackermann, P., Hofstatter, L., and Kountz, W. B., Concentration of free valine, tryptophane, and histidine of plasma of young and old individuals, as determined with the microbiologic method. J. Lab. \& Clin. Med., 1949, 34, 234.

26. Haurowitz, F., Fortschritte der Biochemie. Basal, 1948, p. 108.

27. Macheboeuf, M. A., and Duboy, J., Precipitation of serum albumins and the lipids which accompany them with ammonium sulfate at different $\mathrm{pH}$ values. Compt. Rend. Soc. de Biol., 1939, 132, 272.

28. Hewitt, L. F., Separation of serum albumin into two fractions. Biochem. J., 1936, 30, 2229.

29. Hanke, M. E., and Sheffner, A. L., Unpublished data.

30. Hier, S. W., Influence of ingestion of single amino acids on the blood level of free amino acids. J. Biol. Chem., 1947, 171, 813.

31. (a) Frankl, W., and Dunn, M. S., The apparent concentration of free tryptophane, histidine and cystine in normal human urine measured microbiologically. Arch. Biochem., 1947, 13, 93.

(b) Dunn, M. S., Camien, M. N., Shankman, S., and Block, H., Urinary excretion of twelve amino acids by normal male and female subjects measured microbiologically. Arch. Biochem., 1947, 13, 207.

32. Woodson, H. W., Hier, S. W., Solomon, J. D., and Bergeim, O., Urinary excretion of amino acids by human subjects on normal diets. J. Biol. Chem., 1947, 172, 613.

33. Eckhardt, R. D., and Davidson, C. S., Urinary excretion of amino acids by a normal adult receiving diets of varied protein content. J. Biol. Chem., $1949,177,687$.

34. Harper, H. A., Kinsell, L. W., and Barton, H. C., Plasma L-methionine levels following intravenous administration in humans. Science, 1947, 106, 319.

35. Smyth, C. J., Levey, S., and Lasichak, A. G., The effects of the rate of administration of amino acid preparations on urinary wastage of amino acid nitrogen in man. J. Clin. Invest., 1948, 27, 412.

36. Hanke, M. E., A crystalline protein from normal human urine. J. Biol. Chem., 1940, 133, xl.

37. Sauerblich, H. E., Pearce, E. L., and Baumann, C. A., Excretion of amino acids by rats and mice fed proteins of different biological values. J. Biol. Chem., 1948, 175, 29. 